\title{
PUBLIC GOVERNANCE DAN KORUPSI: BUKTI PENGUJIAN DARI INDONESIA MENGGUNAKAN PERSPEKTIF TEORI KEAGENAN
}

\section{PUBLIC GOVERNANCE AND CORRUPTION: PROOF OF TESTING FROM INDONESIA USING AGENCY THEORY PERSPECTIVE}

\author{
Evi Maria ${ }^{1)}$ and Abdul Halim ${ }^{2)}$ \\ Universitas Kristen Satya Wacana, Indonesia ${ }^{1)}$, Universitas Gadjah Mada, Indonesia ${ }^{2}$ \\ evi.maria@uksw.edu ${ }^{1)}$,ahali58@ugm.ac.id ${ }^{2)}$
}

\begin{abstract}
This article explores public governance impact on the corruption's probability in Indonesian local government practices. The research employs data of Indonesian local governments in 2012. Data were analyzed using logistic regression. The study results found that good public governance has a negative effect on corruptio's probability. The results of this research conclude that the greater public governance index, the less the local government's engagement in corruption. The results are rugged when area type is added as control variable. Area type do not affect the corruption's probability in Indonesian local governments. This study found good public governance decreases the asymmetry of information between agents and principals, so that the opportunity to commit corruption are reduced. Improvement of public governance can be done by implementing e-Government to supervise the implementation of government activities and public services in local government, Indonesia.
\end{abstract}

Keywords: agency theory, corruption, e-Government, local governments, public governance

*Corresponding author :

Email: evi.maria@uksw.edu

DOI: https://doi.org/10.33369/j.akuntansi.11.3.223-234

\section{PENDAHULUAN}

Tata kelola menjadi isu utama penyelenggaraan pemerintahan (Hofheimer 2006). Tata kelola pemerintahan di Indonesia disebut dengan istilah public governance oleh Komite Nasional Kebijakan Governance (KNKG, 2008). Penelitian ini menggunakan isitilah public governance untuk menyebut tata kelola penyelenggaraan pemerintahan. Public governance adalah aturan perilaku dalam kegiatan penyelenggaraan negara secara akuntabel dan penuh rasa tanggungjawab. Interaksi dalam public governance selalu melibatkan empat aktor, yaitu birokrasi, pemerintah, masyarakat sipil dan ekonomi. Ini berarti public governance yang baik, tidak hanya tanggungjawab dari pemerintah tetapi juga membutuhkan peran dari pihak-pihak lainnya.

Public governance yang baik diyakini oleh Khan (2006), Hofheimer (2006) dan Nguyen et al. (2017) dapat menurunkan tingkat korupsi suatu negara. Zhang (2016) menemukan peningkatan public governance dapat mengurangi probabilitas fraud di perusahaan. Ini berarti public governance memiliki pengaruh terhadap corporate governance. Pemerintah memiliki peran sebagai alat pengawasan eksternal setiap keputusan yang diambil oleh perusahaan. Temuan Hofheimer (2006), Zhang (2016) dan Nguyen et al. (2017) tersebut, mendorong banyak negara untuk menerapkan public governance yang baik, tidak terkecuali di Indonesia. Namun, kondisi geografi dan lingkungan politik yang berbeda antar negara membuat tidak ada jaminan bahwa tata kelola memiliki pengaruh yang sama dalam upaya menekan korupsi (Hofheimer, 2006; Khan, 2006). Karakteristik tata kelola pemerintahan yang baik antar negara pun tidak bisa menjadi seragam. Kondisi ini mendorong negara-negara untuk menyusun dan mengembangkan rancangan public governance yang cocok dengan kondisi di negaranya masing-masing. 
Di Indonesia, public governance yang baik sudah mendapat fokus perhatian sejak tahun 1999. Prinsip-prinsip penyelenggaran pemerintahan yang baik diatur di UU No. 28/1999 tentang Penyelenggaraan Negara yang Bersih dan Bebas dari Korupsi, Kolusi dan Nepotisme. UU ini, mengatur indikator keberhasilan public governance adalah pemerintah yang bebas dari praktik korupsi. Pemerintah terus menerus berupaya memperbaiki dan mengembangkan public governance, misalnya saja dengan memberlakukan program reformasi birokrasi di tahun 2010. Program ini diatur lebih detail dalam Peraturan Presiden No. 81/2010 tentang Grand Design Reformasi Birokrasi tahun 2010-2025. Selain itu, pemerintah juga melakukan reformasi manajemen keuangan publik dengan berfokus pada peningkatan pengendalian keuangan, pelaporan keuangan, transparansi dan akuntabilitas. Harapannya agar kegiatan pelayanan publik dan penyelenggaraan negara yang bebas praktik korupsi dapat segera tercapai.

Fakta di lapangan jauh dari harapan. Penerapan public governance tidak serta merta membuat praktik korupsi berkurang. Korupsi di pemerintah daerah terjadi hampir di seluruh bagian organisasi (Maria et al., 2019a). Di Indonesia, tidak sedikit pejabat pemerintah yang terjerat kasus korupsi. Komisi Pemberantasan Korupsi (2019) mencatat ada 119 kepala daerah, yaitu 17 Gubernur, 79 Bupati dan 23 Walikota yang kasusnya ditangani oleh KPK sepanjang sepanjang tahun 2004-2019 dan terbukti melakukan tindak pidana korupsi. Di negara berkembang korupsi adalah praktik yang lazim terjadi (Kolstad and Wiig 2011). Korupsi menyebabkan kerusakaan kondisi sosial dan ekonomi (Otusanya 2011). Korupsi berdampak negatif pada pertumbuhan ekonomi (Elbahnasawy, 2014), stabilitas politik serta menurunkan tingkat kepercayaan investor dan masyarakat terhadap pemerintah (Rothstein and Varraich 2017). Nguyen et al. (2017) juga menemukan ada hubungan negatif antara praktik korupsi dengan kualitas pelayanan publik, khususnya pada pelayanan di bidang pendidikan dan kesehatan. Kondisi ini membuat public governance masih menjadi isu yang masih relevan untuk diteliti untuk konteks pemerintah daerah di Indonesia.

Penelitian terdahulu telah meneliti pengaruh public governance pada pengelolaan pemerintah daerah (lihat penelitian Kristiansen et al., 2009; Saputra, 2012; Masyitoh et al., 2015; Rahmawati, 2015; Setyaningrum et al., 2017). Penelitian Kristiansen et al. (2009) mengidentifikasi transparansi perlu terus ditingkatkan oleh pemerintah daerah untuk mencapai tata kelola yang baik. Saputra (2012) menemukan bahwa akuntabilitas memiliki peran untuk menurunkan dampak negatif dari penerapan desentralisasi. Masyitoh et al. (2015) menemukan pelaksanaan akuntabilitas terbukti dapat menurunkan tingkat korupsi. Sedangkan, Rahmawati (2015) mengidentifikasi partisipasi masyarakat, transparansi dan akuntabilitas adalah karakteristik governance yang baik di Inspektorat Kabupaten Bulu. Penelitian-penelitian tersebut, hanya menggunakan ukuran tunggal untuk proksi public governance yang baik, seperti akuntabilitas, transparansi dan partisipasi.

Setyaningrum et al. (2017) telah mencoba untuk membangun indeks komprehensif public governance yang baik menggunakan lima prinsip yang dikembangkan oleh KNKG, antara lain demokrasi, transparansi, akuntabilitas, budaya hukum, kewajaran dan kesetaraan. Hasil penelitian menemukan bahwa public governance yang baik berpengaruh menurunkan tingkat korupsi dan korupsi yang rendah akan membuat kualitas layanan publik meningkat. Namun penelitian Setyaningrum et al. (2017) masih memiliki dua keterbatasan. Pertama, pengembangan indikator public governance mengabaikan pendapat dari ahli, sehingga indikator dikembangkan dengan unsur subyektivitas yang tinggi. Kedua, korupsi tidak tepat diukur menggunakan jumlah keluhan publik. Ini karena korupsi adalah perbuatan melawan hukum, sehingga perbuatan diklasifikasikan sebagai tindak pidana korupsi jika perbuatan tersebut telah memperoleh putusan inkracht dari Mahkamah Agung (Maria et al., 2019b). Kondisi inilah yang membuat penelitian untuk menguji kembali pengaruh public governance yang baik terhadap korupsi dengan memperbaiki pengukuran konstruk korupsi dan indeks 
komprehensif konstruk public governance yang sudah dilakukan oleh Setyaningrum et al. (2017) masih perlu untuk dilakukan.

Kontribusi penelitian ini, antara lain pertama, hasil penelitian ini berkontribusi untuk pengembangan ilmu di bidang Akuntansi Publik dengan menyediakan bukti pengujian bahwa public governance merupakan salah satu faktor penting yang dapat mengeliminasi peluang terjadinya praktik korupsi di organisasi sektor publik. Kedua, hasil penelitian berkontribusi untuk pemerintah yang berperan dalam membuat kebijakan publik, karena hasil penelitian memberi informasi terkait keefektifan implementasi public governance dalam upaya memberantas praktik korupsi di Indonesia. Hasil penelitian ini juga menyediakan informasi terkait peran penting dari implementasi public governance dalam pengawasan kegiatan penyelenggaraan pemerintahan dan/atau pelayaanan publik di Indonesia.

Klitgaard (1988) menjelaskan korupsi di pemerintah menggunakan perspektif teori keagenan. Asumsi teori keagenan, ada ketidak selarasan kepentingan antara agen dan prinsipal, sehingga memicu perilaku oportunistik dari agen (Jensen dan Meckling, 1976; Eisenhardt, 1989; Baiman, 1990). Di pemerintah daerah, agen adalah pegawai pemerintah dan masyarakat adalah pinsipal sebagai pemilih dari politisi yang memimpin daerah (Zimmerman 1977). Tingkat akuntabilitas yang rendah, monopoli kekuasaan serta diskresi besar dalam aktivitas pengambilan keputusan adalah faktor pendorong terjadinya korupsi di pemerintah (Klitgaard, 1988).

Pejabat pemerintah memiliki lebih banyak informasi daripada masyarakat karena pemerintah merupakan penyelenggara pemerintahan. Asimetri informasi antara prinsipal dan agen membuka kesempatan bagi agen untuk melakukan perbuatan ilegal (Klitgaard, 1988). Saat agen melakukan monopoli terhadap akses informasi dan kekuasaan, maka korupsi akan sangat mudah terjadi di sana (Klitgaard, 1988; Elbahnasawy, 2014). Korupsi terjadi jika agen mengambil untung dari kepercayaan yang diberikan kepadanya untuk kepentingan pribadi dan/atau kelompoknya dan agen mengorbankan kepentingan publik. Skema kecurangan, seperti penyuapan, penipuan, nepotisme, penggelapan serta pemerasan dapat dilakukan oleh agen karena asimetri informasi yang terjadi dalam sebuah organisasi (Lio et al., 2011)

Korupsi tidak hanya didorong oleh motif ekonomi (Rose-Ackerman, 1978; Klitgaard, 1998), tetapi juga didorong oleh keinginan untuk mencapai atau mempertahankan kekuasaan politik (Sikka 2008). Tidak sedikit kasus korupsi terjadi pada proses penyusunan anggaran dengan melibatkan tak hanya pihak legislatif, yaitu Dewan Perwakilan Rakyat tetapi juga pihak eksekutif, yaitu kepaladaerah. Motifnya adalah untuk memperoleh keuntungan ekonomi dan merugikan keuangan negara (Maria et al., 2019b). Monopoli kekuasaan dan akses informers dapat dikurangi dengan melakukan restrukturisasi hubungan antar agen dan prinsipal (Klitgaard, 1988). Pemerintah memerlukan tata kelola pemerintahan yang baik. Tata kelola diyakini sebagai satu mekanisme yang dapat digunakan untuk mengurangi korupsi (Hofheimer, 2006; Lio et al. 2011; Elbahnasawy, 2014) dan meningkatkan kesejahteraan rakyat.

Public governance yang baik harus memenuhi prinsip akuntabilitas, transparansi, kewajaran, partisipasi masyarakat, efisiensi dan efektivitas (KNKG, 2008). Akuntabilitas menunjukkan komitmen dan tanggung jawab dari aparatur negara dalam melaksanakan tugasnya. Tanpa akuntabilitas yang memadai dalam pengelolaan negara, praktik korupsi akan meningkat (Klitgaard, 1998; Saputra, 2012; Masyitoh et al., 2015). Transparansi menunjukkan kemudahan masyarakat dalam mengakses informasi ekonomi, sosial dan politik yang terpercaya dan tepat waktu (Kolstad and Wiig 2011). Kurangnya transparansi dalam pengelolaan keuangan daerah membuka kesempatan bagi pejabat pemerintah untuk menggunakan sumber daya publik untuk keuntungan pribadi dan/atau kelompoknya (Kristiansen et al., 2009; Setyaningrum et al., 2017). Kewajaran menunjukkan kepatuhan aparatur negara terhadap standar dan peraturan yang berlaku. Kualitas keputusan dalam organisasi dapat ditingkatkan jika organisasi memiliki informasi keuangan yang wajar (Heuer 
et al., 2007). Akibatnya, tingkat korupsi akan berkurang (Masyitoh et al., 2015). Transparansi dan partisipasi masyarakat memperkuat akuntabilitas dan mengurangi korupsi (Khan, 2006; Nguyen et al., 2017). Efisiensi mengacu pada optimalisasi penggunaan waktu, dana, dan sumber daya manusia dalam upaya menjalankan program dan kebijakan. Sedangkan, efektivitas mengacu pada kondisi pencapaian tujuan dari program dan kebijakan pemerintah, yaitu tercipta masyarakat yang cerdas, adil dan beradab (Kemitraan, 2014). Kebijakan dan program pemerintah dapat menjadi efektif dan efisien jika tidak terjadi praktik korupsi di negara tersebut (Hofheimer, 2006). Dalam rangka memeriksa hubungan antara public governance dan korupsi, maka hipotesis penelitian dinyatakan sebagai berikut:

H1: Public governance yang baik berpengaruh negatif pada probabilitas korupsi terjadi di pemerintah daerah, Indonesia.

\section{METODE PENELITIAN}

\section{Sampel dan Data Penelitian}

Pemerintah daerah di Indonesia merupakan populasi penelitian dan pemerintah daerah provinsi di tahun anggaran (TA) 2012 adalah sampel penelitian. Penelitian ini mengamati kasus korupsi Anggaran Pendapatan Belanja Daerah (APBD) tingkat provinsi TA 2012. Tiga alasan meneliti TA 2012. Pertama, tahun 2012 merupakan tonggak awal keberhasilan penegakan hukum di Indonesia karena lembaga penegak hukum di Indonesia berani memproses kasus korupsi yang dilakukan oleh pejabat aktif pemerintah. Kedua, pemerintah daerah tempat praktik korupsi dan tidak dalam penelitian ini diklasifikasikan berdasarkan kasus korupsi di APBD yang inkracht, yaitu kasus yang sudah memiliki putusan berkekuatan hukum tetap. Persidangan kasus tindak pidana korupsi, memakan waktu yang panjang karena para terdakwa kasus ini diperbolehkan oleh Undang-Undang untuk mengajukan pembelaan mulai dari pengadilan negeri sampai tingkat kasasi di Indonesia. Hasil identifikasi menemukan kasus korupsi dalam APBD provinsi TA 2012 bisa digunakan karena banyak yang sudah memiliki putusan inkracht. Ketiga, penelitian ini menggunakan Indonesian Governance Index (IGI) yang dikembangkan oleh para ahli di bidang pemerintahan dan pemangku kepentingan yang tergabung dalam The Partnership for Governance Reform (Kemitraan). IGI adalah indeks komprehensif public governance dan data IGI seluruh provinsi di Indonesia tahun 2012 tersedia lengkap.

Data sekunder digunakan untuk proses analisisnya. Data terkait tindak pidana korupsi didapatkan dari pemetaan putusan Mahkamah Agung (MA). Data tersebut diperoleh dari website MA. Sedangkan, nilai indeks kinerja public governance diperoleh dari Kemitraan. Sampel penelitian ini, yaitu 33 pemerintah daerah provinsi. Tahun 2012, Indonesia hanya memiliki 33 pemerintah daerah provinsi. Provinsi Kalimantan Utara baru ditetapkan sebagai provinsi ke-34 pada akhir tahun 2012, sehingga provinsi ini belum memiliki IGI dan tidak masuk dalam sampel penelitian ini.

Teknik pemilihan sampel, yaitu non-random karena pertimbangan jumlah data indeks public governance dan korupsi yang sudah memiliki putusan inkracht dari MA jumlahnya juga masih terbatas. Kondisi ini tidak memungkinkan menggunakan sistem random. Sampel dipilih menggunakan metode purposive sampling kriteria pemerintah memiliki indeks tata kelola yang dikeluarkan oleh Kemitraan.

\section{Variabel Operasional dan Pengukuran}

Variabel didefinisikan sebagai faktor-faktor dalam penelitian yang akan dianalisis. Variabel tersebut, antara lain variabel korupsi, public governance dan wilayah. Tabel 1 merangkum definisi operasional dan pengukuran variabel dalam penelitian ini. 
Tabel 1. Pengukuran Variabel Penelitian

\begin{tabular}{lll}
\hline Variabel & Kode & \multicolumn{1}{c}{ Pengukuran } \\
\hline Korupsi & Korup & $\begin{array}{l}\text { Skor 1, jika ada praktik korupsi di pemerintah provinsi, skor 0, jika tidak } \\
\text { ada praktik korupsi di pemerintah provinsi. }\end{array}$ \\
\hline Public Governance & PG & Indonesian Governance Index (IGI) untuk pemerintah provinsi. \\
\hline Wilayah & $\mathrm{W}$ & $\begin{array}{l}\text { Skor 1, diberikan pada pemerintah provinsi yang ada di Pulau Jawa, skor } \\
\text { 0 diberikan pada pemerintah provinsi yang ada selain di Pulau Jawa. }\end{array}$ \\
\hline
\end{tabular}

\section{Korupsi di Pemerintah Daerah}

Penelitian ini menggunakan definisi korupsi seperti yang diatur dalam UU No. 31/1999 jo. UU No. 20/2001 tentang Pemberantasan Tindak Pidana Korupsi pasal 2, yaitu :
"setiap orang yang secara melawan hukum melakukan perbuatan memperkaya diri sendiri atau orang lain atau suatu korporasi yang dapat merugikan keuangan Negara atau perekonomian Negara, dipidana,.. ".

Pemberian skor 0 jika tidak ada korupsi di pemerintah daerah dan skor 1 jika ada korupsi di pemerintah daerah pada APBD TA 2012 yang sudah memiliki putusan inkracht dari Mahkamah Agung dilakukan untuk mengukur korupsi dalam penelitian.

\section{Public Governance}

Penelitian ini menggunakan definisi public governance, yaitu proses penyusunan dan pelaksanaan kebijakan, peraturan, serta prioritas pembanggunan melalui interaksi antara eksekutif, legislatif dan birokrasi dengan partisipasi dari masyarakat dan masyarakat ekonomi (Kemitraan, 2014). Public governance diukur menggunakan Indonesian Governance Index (IGI) yang diterbitkan oleh The Partnership for Governance Reform (Kemitraan). IGI merupakan ukuran kinerja tata kelola pemerintah menggunakan indikator yang terukur dan obyektif. IGI dikembangkan melalui diskusi secara intensif dan ekstensif dengan para stakeholder dan para ahli. Tujuannya, untuk memastikan validitas dan reliabilitas dari konsep dan indikator yang dikembangkan. Kinerja pemerintah mengacu pada empat aktor, yaitu birokrasi, pemerintah, masyarakat sipil dan ekonomi terhadap prinsip dari public governance, yaitu partisipasi, keadilan, akuntabilitas, transparansi, efisiensi dan efektifitas. Konseptualisasi kerangka IGI dituangkan dalam matriks 4x6, disilangkan dengan prinsip public governance dan arena.

Empat aktor yang berperan dalam praktik public governance, yaitu pertama, birokrasi. Pelaksana kebijakan yang memiliki peran melayani maupun sebagai jembatan antara pemerintah dan masyarakat disebut birokrasi. Indikator yang dinilai, yaitu pengumpulan pendapatan, pelayanan publik, dan pengaturan kegiatan ekonomi. Kedua, pemerintah, yaitu pembuat kebijakan yang mencakup pihak eksekutif dan legislatif. Indikator yang dinilai, yaitu kerangka kebijakan, penganggaran, kordinasi pembangunan, dan pengawasan pembangunan. Ketiga, masyarakat sipil, seperti organisasi, asosiasi, forum, serikat buruh, lembaga pendidikan dan penelitian. Indikator yang dinilai, yaitu advokasi dan pemberdayaan masyarakat. Keempat, masyarakat ekonomi, meliputi entitas bisnis dan juga asiosiasi yang bertujuan pada keuntungan. Indikator yang dinilai, yaitu upaya melindungi kepentingan bisnis dan upaya mendorong peningkatan iklim usaha dan pertumbuhan ekonomi. IGI berkisar antara angka 1 (terendah) sampai 10 (tertinggi) dan nilai yang dikeluarkan dinyatakan dalam satuan desimal.

\section{Wilayah}

Penelitian ini memasukan wilayah sebagai variabel kontrol. Argumennya, daerah memiliki kondisi infrastruktur yang berbeda dan ada resistensi elit di setiap daerah pada usaha memberantas praktik korupsi, sehingga ingkat dan deteksi korupsi antara pulai yang satu dan 
lainnya di Indonesia bisa jadi berbeda (Abdullah 2012). Variabel dummy digunakan untuk mengukur variabel wilayah, yaitu skor 1 diberikan kepada pemerintah provinsi yang berada di Pulau Jawa, dan skor 0 diberikan kepada pemerintah provinsi selain yang berada di Pulau Jawa.

\section{Metode Analisis}

Penelitian ini menggunakan alat analisis, antara lain: pertama, membandingkan grup sampel pemerintah daerah, tempat korupsi dan tidak. Tujuannya, memastikan apakah penelitian ini sudah memiliki dua grup sampel yang sama, sehingga dapat dilakukan pengujian selanjutnya. Perbandingan grup sampel mengunakan dua kriteria, tahun dan jenis pemerintahan seperti penelitian Abdullah (2012), Pemadanan dua grup sampel dilakukan pada periode yang sama, yaitu TA 2012. Penelitian ini juga melakukan pemadanan terhadap pemerintah daerah, tempat korupsi dan tidak, berdasarkan jenisnya, yaitu provinsi. Jadi dalam tahap ini, pemerintah provinsi, tempat korupsi akan dibandingkan yang tidak ada korupsi.

Kedua, menguji variabel dalam penelitian menggunakan Wilcoxon Signed-Rank Test. Tujuannya, menjamin dua grup sampel penelitian ini, yaitu pemerintah daerah, tempat praktik korupsi dan tidak, memiliki perbedaan. Variabel dengan $p$-value $<0,05$ adalah variabel yang lolos penujian (Hair et al., 2011). Pengujian dapat dilanjutkan pada tahap berikutnya, jika semua variabel lolos uji di tahap ini.

Ketiga, menguji hipotesis menggunakan analisis regresi logistik. Tujuannya, untuk melihat pengaruh public governance pada probabilitas terjadinya korupsi di pemerintah daerah. Uji Wald dilakukan dalam rangka menguji koefisien regresi secara parsial pada model regresi logistik, dengan tingkat signifikansi $(\alpha) 5$ persen. Koefisien regresi dinyatakan signifikan, jika nilai signifikansi $<5$ persen (Gudono 2012), sehingga hipotesis penelitian didukung. Model regresi logistik penelitian ini disajikan pada persamaan 1.

Keempat, melakukan pengujian tambahan. Pengujian dilakukan dengan memasukkan variabel kontrol, yaitu wilayah ke persamaan 1. Tujuannya, untuk memeriksa kekokohan hasil pengujian tahap sebelumnya serta mendapatkan analisis yang jauh lebih baik dari tahap sebelumnya. Model pengujian tambahan penelitian ini disajikan pada persamaan 2.

$$
\begin{aligned}
& \text { Korup }_{i t}=\beta_{0}+\beta_{1} P G_{i t}+\varepsilon_{i t} \ldots \ldots \ldots \ldots \ldots \ldots . .(1) \\
& \text { Korup }_{i t}=\beta_{0}+\beta_{1} P G_{i t}+\beta_{2} W_{i t}+\varepsilon_{i t} \ldots \ldots(2)
\end{aligned}
$$

Korup adalah pemerintah provinsi, tempat praktik korupsi dan kasusnya sudah inkracht, $i$ adalah pemerintah daerah provinsi, $t$ adalah tahun, $\beta_{0}$ adalah kontanta, $\beta_{1}$ adalah koefisien variabel independen: PG adalah public government, $\beta_{2}$ adalah koefisien variabel kontrol: $\mathrm{W}$ adalah wilayah, $\varepsilon$ adalah variabel pengganggu.

\section{HASIL DAN PEMBAHASAN \\ Statistik Deskriptif dan Analisis Univariat}

Hasil statistik deskriptif dan Wilcoxon-Signed Rank Test mengidentifikasi terdapat 15 provinsi yang ada korupsi di TA 2012 dan sisanya, yaitu 18 provinsi tidak ada korupsi di TA 2012. Wilcoxon-Signed Rank Test berfungsi untuk mengevaluasi beda mean antara pemerintah provinsi, tempat korupsi dan tidak. khusus untuk variabel public governance. Sedangkan variabel wilayah, tidak dilakukan Wilcoxon-Signed Rank Test karena variabel tersebut adalah variabel dummy. Hasil Wilcoxon-Signed Rank Test untuk public governance menunjukkan ada perbedaan yang signifikan antara kedua grup sampel karena $p$-value kurang dari 0,05.

Variabel public governance menunjukkan signifikan positif $(\mathrm{p}<0,015)$. Ini berarti ada perbedaan indeks public governance antara grup sampel pemerintah daerah sebagai tempat praktik korupsi dan grup sampel yang tidak. Pemerintah daerah, tempat korupsi terjadi memiliki 
indeks public governance yang lebih rendah jika dibandingkan dengan pemerintah daerah yang tidak menjadi tempat terjadinya korupsi. Indeks public governance tertinggi dengan nilai IGI sebesar 6,80 dimiliki Provinsi D.I.Yogyakarta, sedangkan indeks public governance terendah dengan nilai IGI sebesar 4,45 dimiliki Provinsi Maluku Utara.

Tabel 2 Statistik deskriptif dan Hasil Wilcoxon-Signed Rank Test

\begin{tabular}{clccc}
\hline Var & & $\begin{array}{c}\text { Korupsi } \\
(\mathrm{n}=15)\end{array}$ & $\begin{array}{c}\text { Tidak Korupsi } \\
(\mathrm{n}=18)\end{array}$ & Z Value Wilcoxon Test \\
\hline$P G$ & Mean & 5,45 & 5,90 & $-2,442$ \\
\cline { 1 - 3 } & Standar deviasi & 0,60 & 0,48 & p-value $=0,015^{*}$ \\
\cline { 1 - 3 } Maksimum & 6,19 & 6,80 & \\
\hline & Minimum & 4,45 & 4,87 &
\end{tabular}

Keterangan: * signifikan pada $\mathrm{p}<0,05$

Sumber: data sekunder yang diolah

\section{Hasil Pengujian Hipotesis}

Analisis regresi logistik digunakan dalam tahap pengujian hipotesis. Hasil uji hipotesis dapat dilihat di Tabel 3. Hasil uji G menunjukkan nilai statistika uji G sebesar 5,699 dan $p$-value $=0,017$. Hasil uji Wald menunjukkan bahwa public governance $(0,033)$ signifikan mempengaruhi probabilitas terjadinya korupsi di pemerintah daerah, Indonesia, sehingga $\mathrm{H}_{1}$ terdukung. Korelasi negatif antara public governance dan korupsi memiliki arti bahwa semakin baik public governance yang dimiliki oleh pemerintah daerah, maka probabilitas terjadinya korupsi disana akan semakin rendah, demikian sebaliknya. Hasil uji atas nilai Nagelkerke $R$ Square menunjukkan nilai Pseudo $R^{2}$ sebesar 0,212. Artinya, public governance mampu menjelaskan kondisi/situasi yang mampu menurunkan probabilitas terjadinya praktik korupsi di pemerintah daerah, Indonesia sebesar 21,2 persen, sedangkan sisanya sebesar 78,8 persen dipengaruhi oleh faktor lain. Secara keseluruhan, model penelitian ini akurat digunakan dalam rangka memprediksi praktik korupsi di pemerintah daerah, Indonesia sebesar 63,6 persen, sedangkan tingkat misklasifikasi dari model ini sebesar 36,4 persen.

Tabel 3 Hasil Pengujian Hipotesis

\begin{tabular}{lllll}
\multicolumn{5}{c}{ Korup $_{i t}=\beta_{0}+\beta_{1} P G_{i t}+\varepsilon_{i t}$} \\
\hline Variabel & B & Wald & Sign & Odds Ratio \\
\hline Public Governance & $-1,627$ & 4,462 & $0,033^{*}$ & 0,196 \\
Constant & 9,092 & 4,332 & 0,038 & \\
\hline LR Index & $5,699(\mathrm{p}<0,017)$ & & \\
\hline Model R & & & \\
\hline$\%$ akurasi & 0,212 & & \\
\hline$\%$ misklasifikasi & $63,60 \%$ & & \\
\hline Keterangan: signifikan pada $\alpha=0,05$ & $36,40 \%$ & & \\
Sumber: data sekunder yang diolah & &
\end{tabular}

\section{Hasil Pengujian Tambahan}

Dalam rangka menguji kekokohan hasil temuan, maka dilakukan pengujian tambahan dengan cara memasukkan wilayah dalam model regresi logistik sebagai variabel kontrol. Tabel 4 menunjukkan bahwa public government yang baik berpengaruh negatif pada probabilitas terjadinya korupsi di pemerintah daerah, Indonesia. Sedangkan, wilayah ditemukan tidak memiliki pengaruh pada probabilitas terjadinya korupsi. Setelah menambahkan wilayah ke dalam model pengujian sebagai variabel kontrol, ditemukan terjadi peningkatan keakuratan model secara keseluruhan. Model meningkat keakuratannya untuk memprediksi korupsi di 
pemerintah daerah menjadi 69,7 persen, sedangkan tingkat misklasifikasi dari model penelitian ini adalah sebesar 31,3 persen.

\begin{tabular}{|c|c|c|c|c|}
\hline \multicolumn{5}{|c|}{$\begin{array}{l}\text { Tabel } 4 \text { Hasil Pengujian Tambahan } \\
\text { Korup }_{i t}=\beta_{0}+\beta_{1} P G_{i t}+\beta_{2} W_{i t}+\varepsilon_{i t}\end{array}$} \\
\hline Variabel & $\mathrm{B}$ & Wald & Sign & Odds Ratio \\
\hline Public Governance & $-1,891$ & 5,021 & $0,025^{*}$ & 0,151 \\
\hline Wilayah & 0,948 & 0,671 & 0,413 & 2,581 \\
\hline Constant & 10,460 & 4,794 & 0,029 & \\
\hline LR Index & \multicolumn{4}{|c|}{$6,863(\mathrm{p}<0,021)$} \\
\hline Model $\mathrm{R}^{2}$ & \multicolumn{4}{|c|}{0,234} \\
\hline$\%$ akurasi & \multicolumn{4}{|c|}{$69,70 \%$} \\
\hline$\%$ misklasifikasi & \multicolumn{4}{|c|}{$31,30 \%$} \\
\hline
\end{tabular}

Keterangan: signifikan pada $\alpha=0,05$

Sumber: data sekunder yang diolah

\section{Diskusi dan Pembahasan}

Hasil pengujian menunjukkan bahwa hipotesis dalam penelitian ini mendapatkan dukungan empiris. Public governance yang diterapkan dengan baik di pemerintah daerah terbukti memiliki pengaruh pada probabilitas terjadinya korupsi. Ada hubungan negatif antara penerapan public governance dan korupsi. Ini berarti semakin baik tingkat penerapan public governance di pemerintah daerah, maka kemungkinan terjadinya korupsi akan semakin rendah, demikian juga sebaliknya. Temuan penelitian ini sejalan dengan temuan penelitian Klitgaard (1998), Hofheimer (2006), Lio et al. (2011), Elbahnasawy (2014), dan Setyaningrum et al. (2017) bahwa public governance yang baik dapat mengurangi tingkat korupsi.

Aktivitas penyelenggaraan negara perlu menerapkan prinsip public governance yang baik, seperti akuntabilitas, transparansi, kewajaran, partisipasi masyarakat, efisiensi dan efektivitas (KNKG, 2008). Prinsip-prinsip ini menjadi panduan bagi Kemitraan ketika mengembangkan 126 indikator untuk mengukur indeks public governance (IGI) untuk pemerintah daerah di Indonesia. Penerapan prinsip public governance yang baik diyakini oleh para peneliti, seperti Klitgaard (1998), Kristiansen et al. (2009), Saputra (2012), Masyitoh et al. (2015), Setyaningrum et al. (2017), Maria dan Halim (2021) dapat mengurangi praktik korupsi di daerah dan/atau negara. Penerapan prinsip-prinsip public governance diyakini dapat merestrukturisasi hubungan antara agen dan prinsipal. Tujuannya agar praktik monopoli kekuasaan dan akses informasi yang dilakukan oleh agen, yaitu aparatur negara dapat dikurangi, sehingga perilaku agen yang mementingkan diri sendiri dan mengorbankan kepentingan publik dapat dihindari (Klitgaard, 1988; Elbahnasawy, 2014; Setyaningrum et al., 2017).

Pemerintah dituntut untuk melakukan pengelolaan daerah dan/atau negara secara terbuka dan jujur. Sumber daya dikelola secara transparan untuk kemakmuran dan kesejahteraan masyarakat. Transparansi membuat penyelenggaran negara yang oyektif dapat dilakukan. Namun, transparansi pengelolaan juga harus diikuti dengan penerapan akuntabilitas dan publikasi yang memadai agar dapat menurunkan probabilitas terjadinya korupsi di pemerintah daerah (Setyaningrum et al., 2017).

Akuntabilitas merupakan wujud pertanggungjawaban agen kepada prinsipal. Oleh sebab itu, penerapannya tidak bisa hanya sekedar untuk memenuhi formalitas saja. Implementasi prinsip public governance diharapkan dapat membuat instansi pemerintah menjalankan aktivitas pelayanan public dengan ekonomis, efisien, efektif. Kesadaran penyelenggara negara dalam implementasi prinsip ini ditemukan dapat menurunkan kesempatan terjadinya korupsi di pemerintah daerah (Setyaningrum et al., 2017; Maria dan Halim, 2021). Akuntabilitas membawa implikasi pada arus keluar informasi yang transparan yang mengharapkan adanya 
opini dan/atau umpan balik dari pihak lain untuk perbaikan dan pengembangan di pemerintah daerah.

Prinsip kewajaran dalam public governance yang baik yang diatur oleh KNKG (2008) menuntut pemerintah untuk taat pada standar dan peraturan yang berlaku dalam kegiatan pengelolaan daerah dan/atau negara serta pelayanan publik. Kondisi ini mendorong pelaporan keuangan sesuai dengan Standar Akuntasi Pemerintahan (SAP) dan ketaatan pada sistem pengendalian internal pemerintah (SPIP) perlu untuk dilakukan pemeriksaan oleh lembaga independen, yaitu Badan Pemeriksa Keuangan (BPK) Republik Indonesia. Tujuannya adalah untuk memberikan jaminan bahwa pemerintah daerah dikelola dengan baik, sehingga kesempatan untuk melakukan korupsi dapat diminimalisir dan/atau dihilangkan (Isnadiva dan Haryanto 2021).

Pemerintah berusaha terus untuk meningkatkan public governance, terkait penerapan prinsip transparansi, akuntabilitas, kewajaran, partisipasi masyarakat, efisiensi dan efektivitas dalam pelaksanaan pelayanan publik di daerah, dengan membangun electronic government ( $e$ Government) (Nugroho, 2014; Kurnia et al., 2017; Simarmata, 2017; Setyobudi dan Setyaningrum, 2019; Maria dan Halim, 2021). Informasi tentang kegiatan layanan publik dan pertanggungjawabannya akan menjadi lebih diakses oleh masyarakat ketika pemerintah daerah menggunakan $e$-Government (Maria dan Halim, 2021). Bagi agen, yaitu pemerintah daerah, $e$ Government berguna untuk melaporkan kegiatan dan kinerjanya, sedangkan bagi prinsipal, yaitu masyarakat e-Government berguna untuk mengawasi pelaksanaan penyelenggaraan pemerintahan dan/atau pelayanan publik. E-Government berguna untuk melacak keputusan dan tindakan dari aparatur negara terkait kegiatan dan pertanggungjawaban pelayanan publik serta memberi kebebasan kepada masyarakat ketika akan bertanya terkait prosedur yang tidak masuk akal yang sedang dan/atau akan diterapkan aparatur negara (Lio et al., 2011). Masyarakat dapat melakukan interaksi secara langsung dengan para penyelenggara negara menggunakan $e$ Government, ketika akan menyampaikan aspirasinya (Ullah et al., 2021).

Temuan penelitian ini mengkonfirmasi temuan penelitian Maria dan Gudono (2017) bahwa public governance yang tidak efektif membuka peluang terjadinya kecurangan di pemerintah daerah, dan juga sebaliknya. Kondisi ini juga didukung dengan temuan pemeriksaan BPK (2013a; 2013b) atas SPIP tahun anggaran 2012, yang menemukan bahwa kebanyakan pemerintah daerah di Indonesia memiliki SPI yang lemah. Oleh sebab itu, upaya untuk meningkatkan public governance yang baik adalah salah satu strategi efektif yang bisa digunakan pemerintah untuk memberantas praktik korupsi yang marak terjadi sekarang ini.

Pengujian tambahan dengan memasukkan wilayah sebagai variabel kontrol, menemukan hasil temuan yang konsisten. Ada korelasi negatif antara public government dan korupsi di pemerintah daerah, Indonesia. Temuan pengujian ini, memperkuat temuan bahwa wilayah tidak berpengaruh pada probabilitas terjadinya korupsi di pemerintah daerah. Temuan ini mengkonfirmasi temuan penelitian Maria et al. (2019b) bahwa korupsi di Indonesia terjadi tidak hanya di pusat pemerintahan dan/atau pusat perekonomian, seperti Pulau Jawa, tetapi korupsi juga terjadi di pulau selain Pulau Jawa. Penambahan variabel wilayah dalam model sebagai variabel kontrol membawa dampak pada peningkatan nilai keakuratan model untuk memprediksi pemerintah daerah, tempat terjadinya korupsi dan tidak menjadi lebih baik.

\section{PENUTUP}

Penelitian ini memberikan bukti empiris bahwa public governance memiliki hubungan negatif terhadap probabilitas korupsi terjadi di pemerintah daerah, Indonesia. Ini artinya, semakin baik tingkat penerapan public governance di pemerintah daerah, maka probabilitas terjadinya korupsi akan semakin rendah, demikian juga sebaliknya. Pengujian tambahan dengan memasukkan variabel wilayah dalam model memberikan temuan yang konsisten. Public governance yang baik memiliki pengaruh negatif pada probabilitas terjadinya korupsi, 
sedangkan wilayah tidak memiliki pengaruh pada korupsi. Alasannya, pusat pemerintahan seperti Pulau Jawa, bukan satu-satunya tempat terjadinya korupso. Korupsi juga tersebar di pulau selain Pulau Jawa. Penerapan public governance yag baik terbukti mengurangi peluang terjadinya korupsi di pemerintah daerah. Ini karena akuntabilitas, transparansi, kewajaran, partisipasi masyarakat, efektif dan efisien yang baik dalam kegiatan penyelenggaraan pemerintahan dan/atau pelayanan publik. Berdasarkan temuan penelitian ini, ada dua implikasi penelitian. Pertama, upaya pemerintah untuk meningkatkan public governance yang baik adalah salah satu strategi efektif untuk memberantas praktik korupsi di Indonesia. Kedua, peningkatan public governance dapat dilakukan dengan menerapkan e-Government sebagai alat pemerintah untuk melaporkan kegiatan dan kinerja, serta mengawasi pelaksanaan kegiatan pemerintahan dan/atau pelayanan publik.

Keterbatasan penelitian ini, ada dua. Pertama, ada bias data dalam mengukur korupsi. Korupsi yang diukur hanya korupsi yang dapat dideteksi oleh para penegak hukum serta kasus korupsi yang sudah inkracht. Faktanya, banyak kasus korupsi yang masih belum dapat dideteksi oleh para penegak hukum di Indonesia. Kondisi ini mendorong penelitian mendatang untuk terus melakukan eksplorasi proksi-proksi lain yang dapat digunakan mengukur korupsi, seperti indeks persepsi korupsi. Kedua, periode amatan hanya satu tahun anggaran. Ini karena Kemitraan pada tahun 2013 hanya melakukan pengukuran IGI pada 34 kabupaten/kota di Indonesia, dan tidak menyediakan data pengukuran di level provinsi. Kemitraan terus melakukan validasi indikator pengukuran IGI mulai dari level provinsi, kabupaten/kota, hingga kementerian. Kondisi ini mendorong penelitian selanjutnya masih perlu mencoba melakukan eksplorasi proksi untuk mengukur public governance di Indonesia dan/atau mencoba mengukur IGI menggunakan instrumen yang dikembangkan oleh Kemitraan.

\section{DAFTAR PUSTAKA}

Abdullah, Syukriy. (2012). Perilaku Oportunistik Legislatif Dan Faktor-Faktor Yang Mempengaruhinya: Bukti Empiris Dari Penganggaran Pemerintah Daerah Di Indonesia. Universitas Gadjah Mada, Yogyakarta.

Baiman, Stanley. (1990). Agency Research in Managerial Accounting: A Second Look Accounting. Organizations and Society 15(4):341-71.

BPK. (2014a). Ikhtisar Hasil Pemeriksaan BPK Semester I Tahun 2014. Jakarta.

BPK. (2014b). Ikhtisar Hasil Pemeriksaan BPK Semester II Tahun 2014. Jakarta.

Eisenhardt, Kathleen M. (1989). Agency Theory: An Assesment and Review. The Academy of Management Review 14(1):57-74.

Elbahnasawy, Nasr G. (2014). E-Government, Internet Adoption, and Corruption: An Empirical Investigation. World Development 57:114-26.

Gudono. (2012). Analisis Data Multivariat. 2nd ed. Yogyakarta: BPFE.

Hair, J., W. Black, B. Babin, and R. Anderson. (2011). Multivariate Data Analysis: A Global Perspective. 7th ed. New Jersey: Pearson Education Limited.

Heuer, Larry, Steven Penrod, and Ayelet Kattan. (2007). The Role of Societal Benefits and Fairness Concerns Among Decision Makers and Decision Recipients. Law and Human Behavior 31:573-610.

Hofheimer, Kerry L. (2006). The Good Governance Agenda of International Development Institutions. Old Dominion University.

Isnadiva, Safira Marsha, and Haryanto. (2021). Hasil Pemeriksaan Dan Kasus Korupsi Pada Pemerintah Studi Pada Pemerintah Daerah Provinsi Di Indonesia Tahun 2015-2018. Jurnal Riset Akuntansi Dan Keuangan 9(1):83-100. 
Jensen, Michael C., and William H. Meckling. (1976). Theory of the Firm: Managerial Behavior, Agency Costs and Ownership Structure. Journal of Financial Economics 3(4):305-60.

Kemitraan (The Partnership for Governance Reform). (2013). Indonesian Governance Index 2012. Jakarta.

Khan, Mushtaq H. (2006). Determinants of Corruption in Developing Countries: The Limits of Conventional Economic Analysis. Pp. 219-44 in International Handbook on the Economics of Corruption. Cheltenham: Edward Elgar Publishing.

Klitgaard, R. (1988). Controlling Corruption. Berkeley: University of California Press.

Klitgaard, Robert. (1998). International Cooperation Against Corruption. Finance and Development 35(1):3-6.

Kolstad, Ivar, and Arne Wiig. (2011). Natural Resources, Corruption and Trust: A Complex Relationship. Vol. December.

Komisi Pemberantasan Korupsi. (2019). Statistik Penindakan Tindak Pidana Korupsi Berdasarkan Profesi Dan Jabatan. Retrieved January 8, 2020 (https://www.kpk.go.id/id/statistik/penindakan/tpk-berdasarkan-profesi-jabatan).

Komite Nasional Kebijakan Governance. (2008). Pedoman Umum Good Public Governance Indonesia.

Kristiansen, Stein, Agus Dwiyanto, Agus Pramusinto, and Erwan Agus Putranto. (2009). "Public Sector Reforms and Financial Transparency: Experiences from Indonesian Districts." Contemporary Southeast Asia: A Journal of International and Strategic Affairs 31(1):64-87.

Kurnia, Titon Slamet, Umbu Rauta, and Arie Siswanto. (2017). E-Government Dalam Penyelenggaraan Pemerintahan Daerah Di Indonesia. Masalah-Masalah Hukum 46(2):170-81.

Lio, Mon Chi, Meng Chun Liu, and Yi Pey Ou. (2011.) Can the Internet Reduce Corruption? A Cross-Country Study Based on Dynamic Panel Data Models. Government Information Quarterly 28(1):47-53.

Maria, E., and Gudono. (2017). Empirical Test of Fraud Triangle Theory on Local Government (Evidence from Indonesia). International Journal of Applied Business and Economic Research 15(4):233-48.

Maria, Evi, and Abdul Halim. (2021). E-Government Dan Korupsi: Studi Di Pemerintah Daerah, Indonesia Dari Perspektif Teori Keagenan. EKUITAS (Jurnal Ekonomi Dan Keuangan) 5(1):40-58.

Maria, Evi, Abdul Halim, Eko Suwardi, and Setiyono Miharjo. (2019a). Desentralisasi Fiskal Dan Probabilitas Terjadinya Korupsi: Sebuah Bukti Empiris Dari Indonesia. Jurnal Ekonomi Dan Bisnis 22(1):1-22.

Maria, Evi, Abdul Halim, Eko Suwardi, and Setiyono Miharjo. (2019b). Eksplorasi Kesempatan Untuk Melakukan Fraud Di Pemerintah Daerah, Indonesia (Exploration Opportunities To Commit Fraud in Local Governments, Indonesia). Jurnal Akuntansi Dan Keuangan Indonesia 16(1):216-32.

Masyitoh, Rizki Diyah, Ratna Wardhani, and Dyah Setyanigrum. (2015). Pengaruh Opini Audit, Temuan Audit, Dan Tindak Lanjut Hasil Audit Terhadap Persepsi Korupsi Pada Pemerintah Daerah Tingkat II Tahun 2008-2010. Pp. 1-26 in Simposium Nasional Akuntansi XVIII. Medan: Ikatan Akuntan Indonesia.

Nguyen, Thang V, Thang Ngoc Bach, Thanh Le, and Canh Quang Le. (2017). Local Governance, Corruption, and Public Service Quality: Evidence from a National Survey in Vietnam. International Journal of Public Sector Management 30(2):137-153.

Nugroho, Edi. (2014). Pemanfaatan Teknologi Informasi Dalam Rangka Memberantas Tindak Pidana Korupsi Secara Elektronik. Jurnal Dinamika Hukum 14(3):539-46. 
Otusanya, Julius Olantunde. (2011). Corruption as an Obstacle to Development in Developing Countries: A Review of Literature. Journal of Money Laundering Control 14(4):387-422.

Peraturan Presiden Nomor 81. (2010). Grand Design Reformasi Birokrasi Tahun 2010-2025. Indonesia.

Presiden Republik Indonesia. (1999). Undang-Undang Republk Indonesianomor 28 Tahun 1999Tentang Penyelenggaraan Negara Yang Bersih Dan Bebasdari Korupsi, Kolusi, Dan Nepotisme.

Rahmawati, A. (2015). Effect on Performance Audit Implementation of Good Corporate Governance in Kab.Luwu (Case Study Inspectorate Kab.Luwu). Journal of Economics and Behavioral Studies 7(1):13-19.

Rose-Ackerman, Susan. (1978). Corruption: A Study in Political Economy. New York: Academic Press.

Rothstein, Bo, and Aiysha Varraich. (2017). Making Sense of Corruption. Cambridge University Press.

Saputra, Bambang. (2012). Dampak Desentralisasi Fiskal Terhadap Korupsi Di Indonesia. Jurnal Borneo Administrator 8(3):293-309.

Setyaningrum, Dyah, Ratna Wardhani, and Akhmad Syakhroza. (2017). Good Public Governance, Corruption and Public Service Quality: Indonesia Evidence. International Journal of Applied Business and Economic Research 15(19):327-38.

Setyobudi, Christan RA, and Dyah Setyaningrum. (2019). E-Government and Corruption Perception Index: A Cross-Country Study. Jurnal Akuntansi \& Auditing Indonesia 23(1):11-20.

Sikka, Prem. (2008). Enterprise Culture and Accountancy Firms: New Masters of the Universe. Accounting, Auditing and Accountability Journal 21(2):268-95.

Simarmata, Markus H. (2017). Dan Media Sosial Untuk Mewujudkan Budaya Transparansi Dan Pemberantasan Korupsi. INTEGRASI 3(2):203-29.

The Partnership for Governance Reform (Kemitraan). (2014). Menata Indonesia Dari Daerah. Jakarta.

Ullah, Atta, Chen Pinglu, Saif Ullah, Hafiz Syed Mohsin Abbas, and Saba Khan. (2021). The Role of E-Governance in Combating COVID-19 and Promoting Sustainable Development: A Comparative Study of China and Pakistan. Chinese Political Science Review 6:86-118.

Undang-Undang Nomor 20. (2001). Perubahan Undang-Undang Nomor 31 Tahun 1999 Tentang Pemberantasan Tindak Pidana Korupsi. Indonesia.

Undang-Undang Nomor 31. (1999). Pemberantasan Tindak Pidana Korupsi. Indonesia.

Zhang, Z. 2016. Public Governance and Coorporate Fraud: Evidence from the Recent AntiCorruption in China. Journal of Business Ethics 1-22.

Zimmerman, Jerold L. (1977). The Municipal Accounting Maze: An Analysis of Political Incentives. Journal of Accounting Research 15:107-44. 